\title{
Inorganic and Organic Pollutant Levels in Soil and Vegetation of a Medium-Sized Urban Area
}

\author{
Barbora Bartošová1 ${ }^{1}$ Tereza Bartošová1, Jiřina Száková1*, Jan Wipler², \\ Zdeněk Košnáŕr , Jana Najmanová 1 , Pavel Tlustoš ${ }^{1}$ \\ ${ }^{1}$ Faculty of Agrobiology, Food and Natural Resources, Czech University of Life Sciences in Prague, \\ Prague, Czech Republic \\ ${ }^{2}$ Department of Clinical Microbiology, Faculty of Medicine and University Hospital Hradec Kralove, \\ Charles University, Czech Republic
}

Received: 30 June 2020

Accepted: 25 January 2021

\begin{abstract}
The adverse effects of anthropogenic activities have led to increasing inorganic and organic contaminant levels in soil and vegetation in highly industrialized areas and megapolitan regions. In this study, the status of risk elements ( $\mathrm{As}, \mathrm{Be}, \mathrm{Cd}, \mathrm{Co}, \mathrm{Cr}, \mathrm{Cu}, \mathrm{Mo}, \mathrm{Ni}, \mathrm{Pb}, \mathrm{V}$ and $\mathrm{Zn}$ ) and polycyclic aromatic hydrocarbons (PAHs) in soils of the medium-sized (100,000 inhabitants) city Hradec Králové (Czech Republic) was assessed. In total, 86 sampling points were established; we collected soil samples as well as the aboveground parts of the plant species dandelion (Taraxacum sect. Ruderalia) and doorweed (Polygonum aviculare), occurring at all sampling points. Elevated values of As (up to $51 \mathrm{mg} / \mathrm{kg}$ ) and $\mathrm{Cd}$ (up to $3.0 \mathrm{mg} / \mathrm{kg}$ ) were found in soils; the high mobility of $\mathrm{Cd}$ in these soils resulted in elevated $\mathrm{Cd}$ contents in T. sect. Ruderalia at several hotspots. The element contents, mobility and interrelationships in the soil, however, indicated mainly geogenic sources of these elements. Low PAH contents were found in the soils, suggesting a low environmental risk in this city, which is mainly due to the absence of industrial plants and high traffic density.
\end{abstract}

Keywords: risk elements, polyaromatic hydrocarbons, soil, plant accumulation

\section{Introduction}

Risk elements, such as $\mathrm{As}, \mathrm{Cd}, \mathrm{Cr}, \mathrm{Cu}, \mathrm{Ni}, \mathrm{Pb}, \mathrm{Zn}$ belong to the frequently discussed potential pollutants of the urban environment. The main sources of these elements in urban soils are mainly derived from

*e-mail: szakova@af.czu.cz traffic and industrial emissions [1]. The elevated risk element contents in the urban industrial areas were already reported (especially in the large cities), and the ecological and human health risks were confirmed [2]. Long-term human exposure to risk elements in the urban areas (for instance via inhalation or ingestion of the contaminated urban dust) can be even associated with increased mortality, mainly due to respiratory symptoms, cardiovascular problems, lung cancer, reduced lungs function, etc. [3]. Among the 
wide range of organic pollutants, polycyclic aromatic hydrocarbons (PAHs) are of particular importance; they are ubiquitous contaminants entering the environment from both natural and anthropogenic sources. The main anthropogenic sources are incineration technologies producing electricity and thermal energy, waste incineration, road traffic and motor vehicles, aircraft, boats, steam and diesel-electric locomotives and some industrial technologies. Besides these main sources, a number of other, less significant sources exist, such as working with hot tar, asphalt pavement wear and tire wear-off during vehicle operation [4]. Ehigbor et al. [5] have investigated PAH contents functional areas (cemetery, commercial, industrial and residential areas) of the Nigerian megacity, Lagos, where the total PAH concentrations varied in the wide range between 0.11 and $15.58 \mathrm{mg} / \mathrm{kg}$. Masto et al. [6] found that the PAH contents in street dust of a coal mining area in India originated from pyrogenic (coal combustion and traffic emission) and petrogenic (coal dust, tyre and road particles) sources. Similarly, Gunawardena et al. [7] and Wawer et al. [8] considered traffic as the main source of PAHs in urban areas.

Traffic represents a significant risk of soil contamination worldwide. For instance, the high $\mathrm{Cd}$ contents in the soils at the Tibetan Plateau in regions with high traffic densities pose a considerable ecological risk [9]. Ben Seghier and Bouhadjera [10] assessed the $\mathrm{Pb}, \mathrm{Cr}, \mathrm{Cd}$, and $\mathrm{Cu}$ in agricultural soils near intensive traffic areas in two major cities in western Algeria, where the total element contents in soils exceeded the environmental quality standards of soil in Europe. Similar results were determined by Liu et al. [11] in urban park soils in Beijing, China. They observed the total average concentrations of $\mathrm{Zn}, \mathrm{Cr}$, $\mathrm{Pb}, \mathrm{Cu}, \mathrm{Ni}, \mathrm{As}, \mathrm{Hg}$, and $\mathrm{Cd}$ were 145.68, 63.57, 36.43, $35.49,27.12,11.97,0.87$ and $0.49 \mathrm{mg} / \mathrm{kg}$, respectively, where except for $\mathrm{Cr}$ and $\mathrm{Ni}$, the contents exceeded the background values. Wang et al. [12] investigated five geographic areas to reflect the different land use and traffic conditions in Zhaoyuan, China. They found that the risk element contents in roadside soils i) decreased with rising altitude and increasing distance from the trunk and branch roads on both sides, and ii) were affected by traffic volume. Different patterns of elements have been observed by Ojuri et al. [13] along a frequented highway in Nigeria. The authors reported decreasing $\mathrm{Zn}$ and $\mathrm{Pb}$ contents in roadside soils with increasing distance from the road, while $\mathrm{Cr}$ and $\mathrm{Ni}$ showed significant increases; in contrast, $\mathrm{Cu}$ showed no significant difference. Decreasing $\mathrm{Pb}$ contents in soil and vegetation with increasing distance from the highway has also been observed by Viard et al. [14], where the maximum contamination levels were determined up to $20 \mathrm{~m}$ from the road. Modlingerová et al. [15] investigated the contents of $\mathrm{As}, \mathrm{Cd}, \mathrm{Cr}, \mathrm{Cu}, \mathrm{Mo}$, $\mathrm{Ni}, \mathrm{Pb}$ and $\mathrm{Zn}$ in soil and vegetation in the vicinity of a selected section $(1 \mathrm{~km})$ of a highly frequented highway as affected by the distance from the roadway $(1,35$ and $70 \mathrm{~m})$. The element contents did not exceed the maximum permissible limits for both soils and plants, but the elements were tightly related to atmospheric deposition caused by traffic; i.e. $\mathrm{Pb}$ and $\mathrm{Zn}$ tended to decrease in soils with increasing distance from the roadway. In addition, site age can play an important role in risk element accumulation in roadside soils [16]. Carrero et al. [17] concluded that there is a decreasing trend in element contents with increasing depth and distance to the road; however, this clear behaviour can only be observed in the case of relatively old roads (more than 15 years), but not in new roads or roads with low traffic densities.

In contrast to risk elements, PAHs in the soil are biodegradable and can be decomposed by the soil microbiota. Biodegradation occurs predominantly in the upper layer of the soil and decreases with the depth of the soil profile [18]. However, aging of the soil contaminants can adversely affect their availability for transformation processes and, therefore, suppresses their bioavailability, as demonstrated for instance by Duan et al. [19]. These authors observed in a model laboratory experiment decreasing benzo(a)pyrene extractability with ageing. As a result, PAH decomposition in the soil is a complex and prolonged process. The five-ring hydrocarbons can remain in the soil for even two years [4]. Thus, high loads of PM (for instance due to high industrial activity) can result in enhanced PAH contents in these soils [20].

Contamination of the urban environment, including the soil and vegetation, within has been predominantly investigated in large cities or megapolitan areas characterised by highly developed industries and high traffic density [11, 21-23] or in the areas strongly affected by mining and smelting industries, coal power plants, etc. $[6,24]$. However, the situation in smaller, less industrialized cities has rarely been investigated. Usually, the environment in a such areas is considered as relatively clean, without significant risks for the population. The city Hradec Králové (Czech Republic) is located in Eastern Bohemia in a relatively flat area, with a high number of green areas and the absence of heavy industry. Industrial activities (chemical, electrical and food processing industries) are concentrated in small enterprises. However, compared to similar cities in the Czech Republic, the town is characterized by a high traffic density. Although Hradec Králové does not exhibit extreme levels of atmospheric contamination, the Czech Hydrometeorological Institute occasionally observed high annual average concentrations of benzo(a)pyrene, exceeding the maximum allowable concentrations. While air quality in the city is regularly monitored, the contents of contaminants in soils and vegetation are not systematically controlled. Thus, the main objective of this study was to describe the levels of risk elements and PAHs in soil and vegetation in Hradec Králové in relation to local anthropogenic activities. 


\section{Material and Methods}

\section{Experimental Site and Sampling}

Hradec Králové is the largest city in Eastern Bohemia. It covers an area of $52 \mathrm{~km}^{2}$ and has about 100,000 inhabitants. Hradec Králové is considered as a city with an unpolluted environment and characterised by a high number of city parks and other green recreation areas. For this study, we selected 86 sampling points within the city area, representing city parks, areas around the hospital and the university, parking lots next to supermarkets and trade centres as well as streets with a high traffic density. The individual sampling points were situated between $50^{\circ} 11^{\prime} 36.96^{\prime \prime} \mathrm{N}$; $15^{\circ} 52^{\prime} 04.12^{\prime \prime} \mathrm{E}$ and $50^{\circ} 12^{\prime} 46.02^{\prime \prime} \mathrm{N} ; 1^{\circ} 50^{\prime} 28.39^{\prime \prime} \mathrm{E}$. The sampling points differed in their distance from the roads with the highest traffic density, where the points were located from 3 to $250 \mathrm{~m}$ from the road (the detailed distribution of the sampling points is presented in Fig. 1). Soil samples were collected for each sampling point at a depth of $0-25 \mathrm{~cm}$, where each sample represented an average of three sub-samples taken from each sampling square. Soil samples were air-dried at $20^{\circ} \mathrm{C}$, ground in a mortar and passed through a $2-\mathrm{mm}$ plastic sieve. Representative samples of the aboveground parts of dandelion (Taraxacum sect. Ruderalia) and doorweed (Polygonum aviculare) were collected at all sampling points. The plant samples were dried at $60^{\circ} \mathrm{C}$ to constant mass and subsequently ground into a fine powder using a laboratory mill. All samples were provided in autumn 2014.

\section{Analytical Methods}

The pseudo-total concentrations of elements in the soils were determined in digests obtained by the following decomposition procedure: Aliquots $(\sim 0.5 \mathrm{~g})$

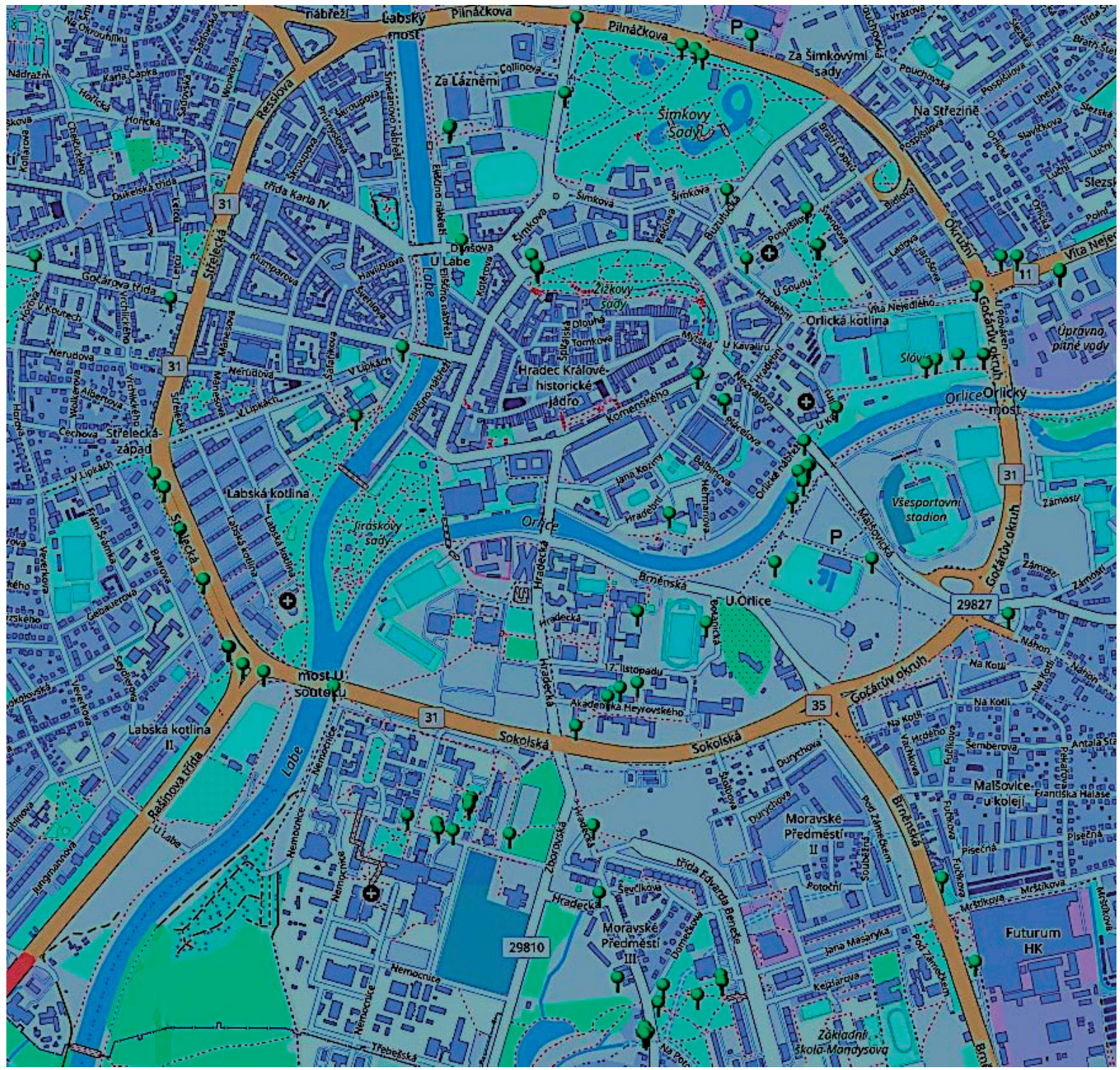

Fig. 1. The detailed distribution of the sampling points (green points in the map) within the investigated area. 
of air-dried soil samples were decomposed in a digestion vessel with $10 \mathrm{ml}$ of Aqua regia (nitric and hydrochloric acid mixture in a ratio of 1:3); the mixture was then heated in an Ethos 1 (MLS GmbH, Germany) microwave-assisted wet digestion system for 33 minutes at $210^{\circ} \mathrm{C}$. After cooling, the digest was quantitatively transferred into a $25-\mathrm{ml}$ glass tube, topped up with deionised water and kept at laboratory temperature until measurements. For determination of element contents in aboveground plant biomass, an aliquot ( $\sim 500 \mathrm{mg}$ of dry matter) of the plant sample was weighed in a digestion vessel. Concentrated nitric acid $(8.0 \mathrm{~mL})$ (Analytika Ltd., Czech Republic) and 30\% $\mathrm{H}_{2} \mathrm{O}_{2}$ (2.0 mL) (Analytika Ltd., Czech Republic) were added. The mixture was heated in an Ethos 1 (MLS GmbH, Germany) microwave-assisted wet digestion system for $30 \mathrm{~min}$ at $220^{\circ} \mathrm{C}$.

For the determination of mobile element fractions in soils, soils were extracted with $2 \mathrm{~mol} \mathrm{~L}^{-1}$ solution of $\mathrm{HNO}_{3}$ at the ratio of $1: 10(\mathrm{w} / \mathrm{v})$ at $20^{\circ} \mathrm{C}$ for 6 hours [25]; each extraction was carried out in three replicates. Subsequently, the extracts were centrifuged in a Hettich Universal $30 \mathrm{RF}$ (Germany) device at 3,000 rpm (i.e. $460 \mathrm{~g}$ ) for 10 minutes at the end of each extraction procedure; the supernatants were kept at $6^{\circ} \mathrm{C}$ prior to measurements. Inductively coupled plasma optical emission spectrometry (ICP-OES, Agilent 720, Agilent Technologies Inc., USA) was used for the determination of elements in soil extracts and plant digests.

For the determination of PAHs in the soils, $15 \mathrm{~g}$ of soil were weighed into a glass flask, mixed with $30 \mathrm{~mL}$ of extraction mixture ( $n$-hexane and acetone in a ratio of 2:1 v/v) (Chromservis, Czech Republic), capped and sonicated (Bandelin Sonorex DT510/H, Germany) for $30 \mathrm{~min}$ at $25^{\circ} \mathrm{C}$. Subsequently, the reaction mixture was shaken in an orbital shaker (GFL 3017, Germany) for $60 \mathrm{~min}$ at $170 \mathrm{rpm}$. Finally, $50 \mathrm{~mL}$ of deionised water were added to separate the hexane and acetone phases; an aliquot $(1 \mathrm{~mL})$ was sampled from the hexane phase and used for PAH determination. Gas chromatography with a mass spectrometric detector (GC-MS, Agilent Technologies Inc., USA) was used for PAH determination, where external calibration curves of the 16 individual compounds of a standard $\mathrm{PAH}$ mixture (Dr. Ehrenstorfer, Germany) were applied for the quantification of signals (peak areas were integrated in this case). The detailed GC-MS instrumentation and chromatographic conditions are described elsewhere [26].

\section{Statistics}

The analytical data were processed using the software package Statistica $10 \mathrm{Cz}$. One-way analysis of variance was used with $\alpha=0.05$ as the criterion for significance, followed by Tukey's test. Correlation analysis was used for the assessment of relationships between variables, where Pearson's correlation coefficients were applied [27].

\section{Results and Discussion}

\section{Risk Element and PAH Contents in Soils}

The pseudo-total (Aqua regia soluble) contents of the investigated elements are summarised in Table 1, where the results document high variability of the concentrations. According to the public notice characterising the conditions for the protection of the agricultural soil quality in the Czech Republic [28], the maximum values of $\mathrm{As}, \mathrm{Be}, \mathrm{Cd}, \mathrm{Cu}, \mathrm{Pb}$ and $\mathrm{Zn}$ exceeded the preventive values of these elements in soil $(20 \mathrm{mg} / \mathrm{kg}$ for As, $2 \mathrm{mg} / \mathrm{kg}$ for Be, $0.5 \mathrm{mg} / \mathrm{kg}$ for $\mathrm{Cd}, 60 \mathrm{mg} / \mathrm{kg}$ for $\mathrm{Cu}, 60 \mathrm{mg} / \mathrm{kg}$ for $\mathrm{Pb}$ and $120 \mathrm{mg} / \mathrm{kg}$ for $\mathrm{Zn}$ ). For $\mathrm{As}$ and $\mathrm{Cd}$, the maximum levels exceeded the indicative values, where the soil element contents represent a potential risk for crop contamination (i.e. $40 \mathrm{mg} / \mathrm{kg}$ for As and $1.5 \mathrm{mg} / \mathrm{kg}$ for Cd). The elevated contents of most of the elements (As, Be, Cd, Cr, $\mathrm{Cu} \mathrm{Ni}$ ) were measured in two city parks. Moreover, as revealed by the correlation analysis, significant $(\alpha=0.05)$ Pearson's correlation coefficients ( $\mathrm{r}$ values varying between 0.27 and 0.92 ) were recorded for these elements, except $\mathrm{Cd}$. The highest levels of $\mathrm{Co}$ and $\mathrm{V}$ were identified within the area of the hospital, maximum Mo and $\mathrm{Zn}$ contents were found close to the soccer stadium, whereas the highest $\mathrm{Pb}$ contents were found in the soil close to a street with high traffic density. Parking lots are considered as local points of increased soil risk element levels within urban areas [29], but in this case, we observed no elevated element contents in the parking lots close to supermarkets. On the contrary, the lowest risk element concentrations were determined in the soil samples from a green recreation area close to the city centre.

As mentioned above, air pollution represents a serious environmental problem, especially in highly industrialised areas or in cities with high population densities. Moreover, pollution levels are often related to high traffic densities, as reported by O'Shea et al. [30] for some risk element contents in road dust in Philadelphia, USA. Similarly, increased element $(\mathrm{Cd}$, $\mathrm{Cu}, \mathrm{Pb}, \mathrm{Zn}$ ) contents have been determined by $\mathrm{Li}$ et al. [31] in urban soils in Hong Kong (China). Fröhlichová et al. [32] investigated risk element levels in soils near train stations in the Czech Republic and found that long-term regular traffic enhanced the element contents (As, $\mathrm{Be}, \mathrm{Cd}, \mathrm{Co}, \mathrm{Cr}, \mathrm{Cu}, \mathrm{Ni}, \mathrm{Pb}$, and $\mathrm{Zn}$ ) in the soils. Li et al. [33] reported that in a Beijing (China) roadside soil, the $\mathrm{Cd}, \mathrm{Cr}, \mathrm{Cu}, \mathrm{Ni}, \mathrm{Pb}$ and $\mathrm{Zn}$ contents ranged from 0.13 to $0.42,46$ to 82,23 to 72,21 to 29,23 to 180 and 65 to $217 \mathrm{mg} / \mathrm{kg}$, respectively. They also calculated the potential health risk by using the maximal hazard quotients and stated that these element levels do not pose potential health effects to children. In this study, the soil element contents in Hradec Králové, a relatively small and green city, were similar and even higher (for $\mathrm{Cd}$ and $\mathrm{Zn}$ ) compared to those in large megapolitan areas. These findings indicate that in our case, soil 
Table 1. The pseudo total contents of the investigated elements in soils.

\begin{tabular}{|c|c|c|c|c|c|c|c|c|c|c|c|}
\hline & $\begin{array}{c}\mathrm{As} \\
\mathrm{mg} / \mathrm{kg}\end{array}$ & $\begin{array}{c}\mathrm{Be} \\
\mathrm{mg} / \mathrm{kg}\end{array}$ & $\begin{array}{c}\mathrm{Cd} \\
\mathrm{mg} / \mathrm{kg}\end{array}$ & $\begin{array}{c}\mathrm{Co} \\
\mathrm{mg} / \mathrm{kg}\end{array}$ & $\begin{array}{c}\mathrm{Cr} \\
\mathrm{mg} / \mathrm{kg}\end{array}$ & $\begin{array}{c}\mathrm{Cu} \\
\mathrm{mg} / \mathrm{kg}\end{array}$ & $\begin{array}{c}\mathrm{Mo} \\
\mathrm{mg} / \mathrm{kg}\end{array}$ & $\begin{array}{c}\mathrm{Ni} \\
\mathrm{mg} / \mathrm{kg}\end{array}$ & $\begin{array}{c}\mathrm{Pb} \\
\mathrm{mg} / \mathrm{kg}\end{array}$ & $\begin{array}{c}\mathrm{V} \\
\mathrm{mg} / \mathrm{kg}\end{array}$ & $\begin{array}{c}\mathrm{Zn} \\
\mathrm{mg} / \mathrm{kg}\end{array}$ \\
\hline Minimum & 3.40 & 0.15 & 0.19 & 1.01 & 6.11 & 8.89 & 0.47 & 2.80 & 17.2 & 7.39 & 24.5 \\
\hline Maximum & 50.8 & 2.60 & 3.03 & 11.3 & 66.8 & 93.2 & 1.59 & 39.4 & 198 & 75.9 & 256 \\
\hline Average & 10.9 & 0.76 & 0.45 & 4.93 & 25.5 & 28.1 & 0.75 & 14.2 & 44.5 & 29.9 & 95.5 \\
\hline Kurtosis & 13.3 & 5.37 & 48.3 & 1.04 & 1.15 & 6.98 & 8.98 & 2.35 & 9.75 & 1.58 & 2.0 \\
\hline Skewness & 2.86 & 1.95 & 6.39 & 0.99 & 0.90 & 1.91 & 1.14 & 1.19 & 2.77 & 1.08 & 1.4 \\
\hline Standard deviation & 6.84 & 0.41 & 0.33 & 2.06 & 11.7 & 12.9 & 0.16 & 6.47 & 29.9 & 13.7 & 46.8 \\
\hline Median & 9.12 & 0.63 & 0.38 & 4.44 & 24.3 & 25.4 & 0.79 & 13.4 & 37.0 & 27.9 & 86.3 \\
\hline MAD & 3.30 & 0.21 & 0.06 & 1.17 & 7.3 & 7.2 & 0.03 & 4.17 & 11.1 & 8.5 & 21.0 \\
\hline
\end{tabular}

${ }^{\mathrm{a}}$ median of absolute deviations

elements remained unaffected by anthropogenic activities.

Linear regression analysis showed that there is no significant relationship between the pseudo-total element contents in the soil and the distance from the road, indicating no influence of traffic on the contents of the analysed risk elements. Due to the significant positive correlation for most elements (except $\mathrm{Cd}$ and $\mathrm{Zn}$ ), we suggest that the levels of these elements in the soil are rather determined by the character of the subsoil. However, this speculation would require more detailed geological and geochemical surveys in this area. The potentially mobilizable $(2 \mathrm{~mol} / \mathrm{L}$ $\mathrm{HNO}_{3}$ soluble) proportions of elements in the soil samples can be helpful for the estimation of the role of anthropogenic contamination. The results summarised in Table 2 suggest the following: i) high variability of elemental concentrations and ii) lower extractability of $\mathrm{Cr}$, Ni and $\mathrm{V}$ compared to the other elements. The extractable proportions of Mo were, in most of cases, below the detection limit of the analytical method. Again, the highest mobilizable element contents in soils were determined in parks (As, $\mathrm{Be}, \mathrm{Pb}$ ) and in the city centre $(\mathrm{Cd}, \mathrm{Co}, \mathrm{Cu}, \mathrm{Zn})$, while the lowest levels of these elements were found in the green recreation area, according to the pseudo-total element contents. Thus, the results show a significant $(\alpha=0.05)$ correlation ( $\mathrm{r}$ values varied between 0.41 and 0.78 ) between the pseudo-total and mobilizable element contents, except for $\mathrm{Cd}$. Mobility and bioavailability of the risk elements in the urban soils of Beijing (China) decreased in the following order: $\mathrm{Cd}>\mathrm{Zn}>\mathrm{Pb}>\mathrm{Cu}>\mathrm{Ni}>\mathrm{Cr}$ [33]. Dehghani et al. [34] stated that $\mathrm{Zn}$ and $\mathrm{Cd}$ are the most easily mobilized elements in urban soils of Tehran, Iran. These findings were confirmed by our investigations. However, low plant-available proportions of $\mathrm{Cu}$ and $\mathrm{Zn}$ in roadside soils of North Carolina (USA) have been reported by Morse et al. [16]. Thus, the effect of particular physicochemical characteristics of soils should be included into the assessment. The mobility

Table 2 . The potentially mobilizable $\left(2 \mathrm{~mol} \cdot \mathrm{L}^{-1} \mathrm{HNO}_{3}\right.$ extractable $)$ contents of the investigated elements in soils.

\begin{tabular}{|c|c|c|c|c|c|c|c|c|c|c|c|}
\hline & $\begin{array}{c}\mathrm{As} \\
\mathrm{mg} / \mathrm{kg}\end{array}$ & $\begin{array}{c}\mathrm{Be} \\
\mathrm{mg} / \mathrm{kg}\end{array}$ & $\begin{array}{c}\mathrm{Cd} \\
\mathrm{mg} / \mathrm{kg}\end{array}$ & $\begin{array}{c}\mathrm{Co} \\
\mathrm{mg} / \mathrm{kg}\end{array}$ & $\begin{array}{c}\mathrm{Cr} \\
\mathrm{mg} / \mathrm{kg}\end{array}$ & $\begin{array}{c}\mathrm{Cu} \\
\mathrm{mg} / \mathrm{kg}\end{array}$ & $\begin{array}{c}\mathrm{Mo} \\
\mathrm{mg} / \mathrm{kg}\end{array}$ & $\begin{array}{c}\mathrm{Ni} \\
\mathrm{mg} / \mathrm{kg}\end{array}$ & $\begin{array}{c}\mathrm{Pb} \\
\mathrm{mg} / \mathrm{kg}\end{array}$ & $\begin{array}{c}\mathrm{V} \\
\mathrm{mg} / \mathrm{kg}\end{array}$ & $\begin{array}{c}\mathrm{Zn} \\
\mathrm{mg} / \mathrm{kg}\end{array}$ \\
\hline Minimum & 1.09 & 0.03 & 0.04 & 0.43 & 0.27 & 2.67 & $<0.050$ & 0.94 & 6.3 & 2.46 & 6.5 \\
\hline Maximum & 20.1 & 1.25 & 1.46 & 4.53 & 27.2 & 33.0 & 0.287 & 7.09 & 193 & 26.3 & 278 \\
\hline Average & 3.58 & 0.36 & 0.23 & 2.06 & 4.12 & 12.7 & 0.125 & 3.69 & 25.7 & 7.33 & 51.3 \\
\hline Kurtosis & 22.9 & 5.15 & 27.3 & 0.50 & 21.3 & 0.37 & 0.968 & 0.13 & 26.0 & 9.00 & 10.5 \\
\hline Skewness & 3.80 & 1.87 & 4.19 & 0.43 & 4.27 & 1.02 & 1.111 & 0.24 & 4.5 & 2.45 & 2.8 \\
\hline Standard deviation & 2.25 & 0.20 & 0.16 & 0.75 & 3.60 & 7.03 & 0.056 & 1.26 & 23.2 & 3.51 & 40.3 \\
\hline Median & 3.06 & 0.33 & 0.21 & 2.01 & 3.38 & 11.0 & 0.110 & 3.67 & 20.4 & 6.63 & 38.6 \\
\hline MAD & 1.43 & 0.14 & 0.09 & 0.57 & 1.80 & 5.47 & 0.005 & 0.99 & 12.3 & 2.37 & 20.8 \\
\hline $\begin{array}{c}\text { \% extractable from } \\
\text { the pseudototal }\end{array}$ & $5.3-88$ & $19-94$ & $5-91$ & $17-85$ & $5-47$ & $10-96$ & $6-44$ & $9-57$ & $10-93$ & $10-58$ & $9-92$ \\
\hline
\end{tabular}

${ }^{a}$ median of absolute deviations 
of risk elements in roadside soils can be enhanced by the application of road salts $\left(\mathrm{NaCl}, \mathrm{MgCl}_{2}\right)$, where the salt application is considered to be the main threat to the ground and water environment during the winter period [35]. Komárek et al. [36], under laboratory conditions, proved that the application of $\mathrm{NH}_{4} \mathrm{Cl}$ into the soil leads to a significant increase in water-soluble contents of $\mathrm{Cd}$ and $\mathrm{Zn}$. In this study, the potential effect of the different soil characteristics on element mobility should be evaluated in further research works, especially in the case of $\mathrm{Cd}$.

The results of the PAH contents in the soil samples are summarised in Table 3. In the public notice describing the conditions for the protection of the soil quality of agricultural regions [28], the preventive value of the sum of the PAHs in soil is set at $1 \mathrm{mg} / \mathrm{kg}$, while the indicative level $30 \mathrm{mg} / \mathrm{kg}$ represents the potential risk for biota. In our study, none of the analysed samples exceeded this value. Moreover, almost $30 \%$ of all the results were below the detection limit of the analytical method. Concerning the individual PAHs, some sampling points showed significant values of the individual risk elements. Maximum anthracene values were found in one the city parks next to the historical centre, and elevated values were also identified close to the swimming pool and along streets with high traffic densities. Also, maximum levels of fluoranthene and chrysene were found close to busy streets. Elevated chrysene levels were also measured close to the swimming pool and in the historical city centre. Maximum levels of other PAHs, such as phenanthrene, pyrene and benzo(a)pyrene, were found at the same sampling points, and the significant Pearson's correlation coefficients $(\alpha=0.05)$ of their interrelationships varied between 0.58 and 0.97 . These results indicate that all determined PAHs originated from one source. However, no significant correlations were recorded for the soil $\mathrm{PAH}$ contents and the distance from the high-traffic streets.

Kotalová et al. [20] investigated the PAH contents in soils in Ostrava city (Czech Republic) with intensive industrial activity (predominantly smelting and steelwork companies); in their study, the sum of the PAHs reached up to $4 \mathrm{mg} / \mathrm{kg}$. Similar values have been published by Bodzek et al. [37] for Zabrze (Poland), a highly industrialised area. Even higher values have been found in the industrial areas in China. Masto et al. [6] determined the PAH values in in the road dusts of a coal mining area (Dhanbad, India), and measured values between 3.98 and $13.1 \mathrm{mg} / \mathrm{kg}$. High PAH values in soils have also been found in the urban soils two large cities in Florida (USA): Orlando and Tampa (3.22 and $4.56 \mathrm{mg} / \mathrm{kg}$, respectively), as reported by Liu et al. [38]. Shamilishvily et al. [39] investigated total PAH contents in soils in large Russian city, Saint Petersburg, and measured PAH contents of up to $8.10 \mathrm{mg} / \mathrm{kg}$. In a similar study, Howard et al. [40], in a study in New Orleans, determined levels of $2.93 \mathrm{mg} / \mathrm{kg}$. In our study, the absence of either intensive industrial activities or extremely high traffic densities results in low soil PAH contents. The PAH levels measured in Hradec Králové are comparable (or even lower) to those found in other urban areas in Europe, such as Caserta provincial territory, southern Italy (median value $0.029 \mathrm{mg} / \mathrm{kg}$ ), differently urbanized soils in Lublin (Poland) (from 0.40 to $2.42 \mathrm{mg} / \mathrm{kg}$ ) and Bratislava, Slovakia $(2.06 \mathrm{mg} / \mathrm{kg}$ ) [41-43]. Our results are therefore in agreement with the findings of other studies in cities unaffected by intensive industry and/or traffic densities.

Kumar et al. [44] investigated the PAH concentrations in car exhausts as affected by fuel type; the authors found that benzo(a)anthracene and benzo(a) pyrene were common at higher concentration, whereas the two-ringed PAHs were present in low concentration in all types of vehicle exhausts. Bao et al. [45] identified phenanthrene, pyrene, benzo(b)fluoranthene, fluorene, and chrysene as the most abundant PAHs in urban soils. In this study, the levels of these compounds were higher compared to those of others (Table 3), indicating the similar fate of the PAHs in the soil. However, the potential degradability of PAHs in soils should be taken into account. Sládková et al. [46] investigated soil PAH values at the former military training base MiloviceMladá (Czech Republic), where military activities were terminated in 1991. Among the PAHs, phenanthrene, pyrene and fluoranthene were the most abundant ones, whereas the concentration of benzo(a)pyrene only reached 5\%. Total PAH contents were relatively low, indicating that the PAHs were degraded during the 20 years after the termination of military activities. Although soil microbial activities were not determined in this study, continuous biodegradation of the PAHs in the soils can be expected; therefore, no significant PAH sinks can be formed in these soils.

\section{Risk Element Contents in the Aboveground Biomass of Plants}

As shown in Tables 4 and 5, all observed As levels were below the detection limit. The contents of the other elements were highly variable, regardless of the sampling point. Comparing the plant species, T. sect. Ruderalia showed a significantly $(\alpha=0.05)$ higher uptake of $\mathrm{Cd}$, whereas $\mathrm{Cr}, \mathrm{Ni}, \mathrm{Pb}$ levels and $\mathrm{V}$ were higher in $P$. aviculare. Correlation analysis did not show unambiguous significant ( $\alpha=0.05$ ) relationships among the individual elements, but the element contents tended to be separated into two groups, showing a similar behaviour for $\mathrm{Cd}, \mathrm{Zn}$ and $\mathrm{Cu}$ on the one hand and for $\mathrm{Be}, \mathrm{Co}, \mathrm{Cr}, \mathrm{Pb}$ and $\mathrm{V}$ on the other hand. Neither distance from the streets nor element contents in soil were related to the element concentrations in plants. Only Co (in T. sect. Ruderalia) and $\mathrm{Pb}(P$. aviculare) contents tended to increase with increasing distance from the street, which is contradictory with other findings. For example, Voutsa et al. [47] assessed the role of air particulate matter $(\mathrm{PM})$-bearing elements $(\mathrm{Cd}, \mathrm{Pb}$, 


\begin{tabular}{|c|c|c|c|c|c|c|c|c|}
\hline$\Sigma$ & & वें &  & $\ddot{n}$ & $\overrightarrow{\hat{y}}$ & $\stackrel{m}{n}$ & $\overrightarrow{\mathrm{g}}$ & $\hat{\dot{\sigma}}$ \\
\hline $\begin{array}{c}\text { Benzo[g,h,i]perylene } \\
\mu \mathrm{g} / \mathrm{kg}\end{array}$ & $\hat{\ddot{v}}$ & $\stackrel{m}{\sim}$ & $\stackrel{m}{a}$ & $=$ & 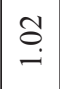 & 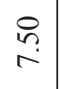 & $\stackrel{\circ}{=}$ & $\stackrel{?}{+}$ \\
\hline $\begin{array}{c}\text { Indeno[1,2,3-c,d]pyrene } \\
\mu \mathrm{g} / \mathrm{kg}\end{array}$ & $\begin{array}{l}\dot{\varphi} \\
\dot{v}\end{array}$ & $\begin{array}{l}\infty \\
\dot{m} \\
\end{array}$ & 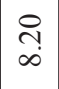 & 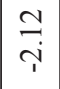 & ָุ̃ & $\begin{array}{l}\mathfrak{r} \\
\stackrel{+}{+}\end{array}$ & $\underset{\mathfrak{I}}{\mathcal{I}}$ & 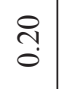 \\
\hline $\begin{array}{c}\text { Dibenzo[a,h]anthracene } \\
\mu \mathrm{g} / \mathrm{kg}\end{array}$ & $\underset{\vec{v}}{\stackrel{\vec{v}}{ }}$ & $\vec{n}$ & $\stackrel{?}{=}$ & $\stackrel{i}{i}$ & 蒙 & $\underset{\iota}{\sim}$ & $\stackrel{+}{\dot{m}}$ & $\begin{array}{l}n \\
6 \\
0\end{array}$ \\
\hline $\begin{array}{c}\text { Benzo[a]pyrene } \\
\mu \mathrm{g} / \mathrm{kg}\end{array}$ & $\stackrel{n}{v}$ & $\stackrel{\grave{\infty}}{\sim}$ & $\begin{array}{l}\infty \\
\dot{j} \\
\end{array}$ & $\overrightarrow{0}$ & $\exists$ & $\begin{array}{c}m \\
\infty \\
\infty\end{array}$ & $\stackrel{a}{\sigma}$ & $\begin{array}{l}\infty \\
\infty \\
0\end{array}$ \\
\hline $\begin{array}{c}\text { Benzo[k]fluoranthene } \\
\mu \mathrm{g} / \mathrm{kg}\end{array}$ & $\stackrel{+}{\vec{V}}$ & $\begin{array}{l}n \\
\infty \\
\infty \\
n\end{array}$ & $\stackrel{n}{ \pm}$ & $\frac{n}{m}$ & $\stackrel{\infty}{\infty}$ & $\stackrel{\circ}{\mathrm{i}}$ & $\stackrel{\circ}{=}$ & 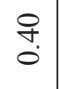 \\
\hline $\begin{array}{c}\text { Benzo[b]fluoranthene } \\
\mu \mathrm{g} / \mathrm{kg}\end{array}$ & $\stackrel{\tilde{v}}{\mathrm{v}}$ & 弪 & $\stackrel{\circ}{9}$ & $\begin{array}{l} \pm \\
\vdots \\
\\
1\end{array}$ & o. & $\stackrel{\sim}{ \pm}$ & $\begin{array}{l}\stackrel{\circ}{ \pm} \\
\dot{ \pm}\end{array}$ & $\begin{array}{l}\infty \\
\infty \\
0\end{array}$ \\
\hline $\begin{array}{c}\text { Chrysene } \\
\mu \mathrm{g} / \mathrm{kg}\end{array}$ & $\begin{array}{l}\dot{\varphi} \\
\dot{v}\end{array}$ & $\begin{array}{l}\infty \\
\dot{f} \\
\end{array}$ & $\begin{array}{l}m \\
\infty \\
-1\end{array}$ & $\stackrel{?}{i}$ & $\stackrel{\beta}{-}$ & $\stackrel{+}{\oplus}$ & $\vec{m}$ & $\stackrel{\bullet}{:}$ \\
\hline $\begin{array}{c}\text { Benz[a]anthracene } \\
\mu \mathrm{g} / \mathrm{kg}\end{array}$ & $\tilde{\tilde{v}}$ & $\stackrel{\sim}{\dot{j}}$ & $\stackrel{a}{\vec{\lambda}}$ & $\stackrel{8}{\grave{i}}$ & $\underset{i}{i}$ & $\begin{array}{l}0 \\
\infty \\
=\end{array}$ & $\begin{array}{l}\infty \\
\dot{0} \\
-\end{array}$ & $\begin{array}{l}\infty \\
\dot{0} \\
\dot{0}\end{array}$ \\
\hline $\begin{array}{l}\text { Fluoranthene } \\
\qquad \mu \mathrm{g} / \mathrm{kg}\end{array}$ & $\stackrel{\vec{v}}{\mathrm{v}}$ & 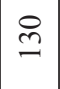 & $\overrightarrow{\grave{i}}$ & $\begin{array}{l}a \\
\infty\end{array}$ & $\begin{array}{l}0 \\
i\end{array}$ & $\stackrel{\bullet}{\vec{\lambda}}$ & $\ddot{n}$ & $\stackrel{a}{0}$ \\
\hline $\begin{array}{l}\text { Pyrene } \\
\mu \mathrm{g} / \mathrm{kg}\end{array}$ & $\stackrel{\tilde{v}}{\mathrm{v}}$ & $\tilde{0}$ & $\stackrel{0}{\infty}$ & $\begin{array}{l}1 \\
\infty \\
\infty\end{array}$ & $\tilde{n}$ & $\stackrel{\imath}{=}$ & $\stackrel{\sim}{\sim}$ & $\stackrel{8}{\circ}$ \\
\hline $\begin{array}{c}\text { Anthracene } \\
\mu \mathrm{g} / \mathrm{kg}\end{array}$ & $\begin{array}{l}\stackrel{0}{\mathrm{~V}} \\
\overrightarrow{\mathrm{V}}\end{array}$ & $\overrightarrow{\vec{r}}$ & $\stackrel{\ominus}{=}$ & $\stackrel{?}{ \pm}$ & $\stackrel{\dot{m}}{\dot{m}}$ & $\exists$ & $\begin{array}{l}0 \\
\infty\end{array}$ & 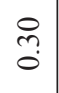 \\
\hline $\begin{array}{c}\text { Phenanthrene } \\
\mu \mathrm{g} / \mathrm{kg}\end{array}$ & $\begin{array}{l}\ddot{v} \\
\ddot{V}\end{array}$ & \begin{tabular}{l}
$n$ \\
\multirow{1}{\infty}{} \\
$\infty$
\end{tabular} & $\stackrel{\check{ \pm}}{\dot{\Xi}}$ & $\stackrel{\sim}{r}$ & $\bar{i}$ & $\vec{i}$ & $\approx$ & $\stackrel{?}{\rightleftarrows}$ \\
\hline $\begin{array}{l}\text { Fluorene } \\
\mu \mathrm{g} / \mathrm{kg}\end{array}$ & $\tilde{v}$ & $\stackrel{\vec{d}}{\rightarrow}$ & $\stackrel{\grave{n}}{i}$ & 号 & $\begin{array}{l}0 \\
0 \\
0 \\
0\end{array}$ & $\underset{f}{\stackrel{f}{+}}$ & $\begin{array}{l}\infty \\
\propto \\
\propto\end{array}$ & $\underset{-\infty}{\infty}$ \\
\hline $\begin{array}{l}\text { Acenaphtene } \\
\mu \mathrm{g} / \mathrm{kg}\end{array}$ & $\tilde{\widetilde{v}}$ & $\ddot{0}$ & $\mid \begin{array}{l}\infty \\
\infty \\
i\end{array}$ &  & $\mid \begin{array}{l}n \\
0 \\
i \\
1\end{array}$ & $\frac{n}{0}$ & $\stackrel{2}{\circ}$ & $\stackrel{?}{\stackrel{n}{*}}$ \\
\hline $\begin{array}{l}\text { Acenaphtalene } \\
\mu \mathrm{g} / \mathrm{kg}\end{array}$ & $\overrightarrow{\vec{v}}$ & $\mid \begin{array}{l}0 \\
n \\
m\end{array}$ & $\begin{array}{l}\stackrel{p}{p} \\
i \\
i\end{array}$ & $\begin{array}{l}0 \\
1 \\
0\end{array}$ & $\begin{array}{l}0 \\
\dot{q} \\
i \\
i\end{array}$ & $\stackrel{\circ}{\rightleftarrows}$ & $\stackrel{\circ}{\stackrel{\circ}{m}}$ & $\stackrel{?}{+}$ \\
\hline \multirow[t]{2}{*}{$\begin{array}{l}\text { Naphtalene } \\
\mu \mathrm{g} / \mathrm{kg}\end{array}$} & $\hat{\vec{v}}$ & 定 & 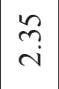 & $\stackrel{R}{i}$ & $\frac{\alpha}{\sigma}$ & ণั. & $\stackrel{n}{i}$ & $\stackrel{n}{0}$ \\
\hline & $\begin{array}{l}\text { 音 } \\
\text { 具 }\end{array}$ & 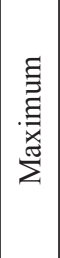 & 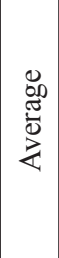 & 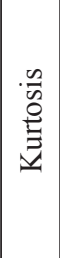 & 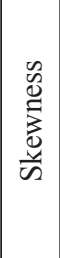 &  & 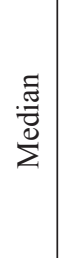 & 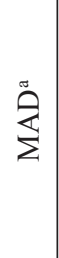 \\
\hline
\end{tabular}


Table 4. The total contents of the investigated elements in aboveground biomass of Taraxacum sect. Ruderalia.

\begin{tabular}{|c|c|c|c|c|c|c|c|c|c|c|c|}
\hline & $\begin{array}{c}\mathrm{As} \\
\mathrm{mg} / \mathrm{kg}\end{array}$ & $\begin{array}{c}\mathrm{Be} \\
\mathrm{mg} / \mathrm{kg}\end{array}$ & $\begin{array}{c}\mathrm{Cd} \\
\mathrm{mg} / \mathrm{kg}\end{array}$ & $\begin{array}{c}\mathrm{Co} \\
\mathrm{mg} / \mathrm{kg}\end{array}$ & $\begin{array}{c}\mathrm{Cr} \\
\mathrm{mg} / \mathrm{kg}\end{array}$ & $\begin{array}{c}\mathrm{Cu} \\
\mathrm{mg} / \mathrm{kg}\end{array}$ & $\begin{array}{c}\mathrm{Mo} \\
\mathrm{mg} / \mathrm{kg}\end{array}$ & $\begin{array}{c}\mathrm{Ni} \\
\mathrm{mg} / \mathrm{kg}\end{array}$ & $\begin{array}{c}\mathrm{Pb} \\
\mathrm{mg} / \mathrm{kg}\end{array}$ & $\begin{array}{c}\mathrm{V} \\
\mathrm{mg} / \mathrm{kg}\end{array}$ & $\begin{array}{c}\mathrm{Zn} \\
\mathrm{mg} / \mathrm{kg}\end{array}$ \\
\hline Minimum & $<0.60$ & 0.001 & 0.04 & $<0.10$ & 0.54 & 5.91 & 0.48 & 0.13 & $<0.40$ & 0.18 & 23.8 \\
\hline Maximum & $<0.60$ & 0.034 & 3.41 & 0.38 & 5.56 & 19.9 & 2.92 & 35.4 & 2.60 & 2.08 & 91.5 \\
\hline Average & - & 0.010 & 0.28 & 0.26 & 2.19 & 11.9 & 0.98 & 2.30 & 1.16 & 0.70 & 54.6 \\
\hline Kurtosis & - & 1.20 & 6.93 & 1.23 & 0.71 & 0.31 & 2.16 & 5.37 & 2.07 & 1.12 & 0.08 \\
\hline Skewness & - & 1.27 & 56.5 & 1.45 & 0.16 & 0.84 & 5.96 & 33.9 & 5.23 & 1.71 & -0.64 \\
\hline Standard deviation & - & 0.008 & 0.38 & 0.05 & 1.07 & 2.58 & 0.45 & 4.64 & 0.45 & 0.37 & 14.7 \\
\hline Median & - & 0.009 & 0.20 & 0.25 & 2.06 & 11.7 & 0.87 & 1.07 & 1.09 & 0.67 & 55.2 \\
\hline MAD & - & 0.006 & 0.16 & 0.16 & 0.86 & 1.94 & 0.03 & 0.10 & 0.10 & 0.27 & 12.6 \\
\hline
\end{tabular}

${ }^{\mathrm{a}}$ median of absolute deviations

Table 5. The total contents of the investigated elements in aboveground biomass of Polygonum aviculare.

\begin{tabular}{|c|c|c|c|c|c|c|c|c|c|c|c|}
\hline & $\begin{array}{c}\mathrm{As} \\
\mathrm{mg} / \mathrm{kg}\end{array}$ & $\begin{array}{c}\mathrm{Be} \\
\mathrm{mg} / \mathrm{kg}\end{array}$ & $\begin{array}{c}\mathrm{Cd} \\
\mathrm{mg} / \mathrm{kg}\end{array}$ & $\begin{array}{c}\mathrm{Co} \\
\mathrm{mg} / \mathrm{kg}\end{array}$ & $\begin{array}{c}\mathrm{Cr} \\
\mathrm{mg} / \mathrm{kg}\end{array}$ & $\begin{array}{c}\mathrm{Cu} \\
\mathrm{mg} / \mathrm{kg}\end{array}$ & $\begin{array}{c}\mathrm{Mo} \\
\mathrm{mg} / \mathrm{kg}\end{array}$ & $\begin{array}{c}\mathrm{Ni} \\
\mathrm{mg} / \mathrm{kg}\end{array}$ & $\begin{array}{c}\mathrm{Pb} \\
\mathrm{mg} / \mathrm{kg}\end{array}$ & $\begin{array}{c}\mathrm{V} \\
\mathrm{mg} / \mathrm{kg}\end{array}$ & $\begin{array}{c}\mathrm{Zn} \\
\mathrm{mg} / \mathrm{kg}\end{array}$ \\
\hline Minimum & $<0.60$ & 0.001 & $<0.02$ & $<0.10$ & 0.90 & 2.36 & 0.33 & $<0.10$ & 0.79 & 0.21 & 16.4 \\
\hline Maximum & $<0.60$ & 0.061 & 0.266 & 0.803 & 17.9 & 19.2 & 1.49 & 50.6 & 6.40 & 4.32 & 113 \\
\hline Average & - & 0.015 & 0.101 & 0.304 & 4.63 & 8.29 & 0.68 & 5.07 & 1.51 & 1.10 & 50.3 \\
\hline Kurtosis & - & 1.53 & 1.37 & 1.75 & 1.59 & 0.77 & 0.99 & 3.77 & 4.21 & 1.81 & 0.81 \\
\hline Skewness & - & 3.39 & 0.908 & 6.59 & 3.52 & 0.55 & 1.52 & 16.4 & 21.2 & 5.17 & 1.21 \\
\hline Standard deviation & - & 0.011 & 0.064 & 0.121 & 3.21 & 3.45 & 0.22 & 8.08 & 0.94 & 0.74 & 18.6 \\
\hline Median & - & 0.012 & 0.080 & 0.281 & 4.29 & 7.63 & 0.66 & 2.63 & 1.32 & 0.96 & 48.3 \\
\hline MAD & - & 0.009 & 0.014 & 0.014 & 2.3 & 2.79 & 0.009 & 0.015 & 0.45 & 0.54 & 13.8 \\
\hline
\end{tabular}

${ }^{\mathrm{a}}$ median of absolute deviations

$\mathrm{Zn}, \mathrm{Cr}$ and $\mathrm{Mn}$ ) in risk element accumulation by leafy vegetables and observed that the root elements were related to the soil element contents, whereas the element contents in leaves were related to the particulate matter elements. Similarly, Kim et al. [48] reported increases in $\mathrm{Cd}, \mathrm{Cr}, \mathrm{Ni}, \mathrm{Pb}, \mathrm{Zn}$ contents in the Brassica rapa ssp. pekinensis plants growing in roadside soil compared with samples collected further away. Also, the PM deposition on tree leaves can be useful for an assessment of the risk element deposition in urban areas [49]. Although the risk element contents in PM significantly exceed those in soils [50], the potential deposition of PM on plant leaves did not result in elevated soil element contents.

Concerning the element contents in plants, the potential input of the element into the food chain via herbivores was assessed. For this, plant element contents were compared with the maximum allowable limits in feedstuffs. For the risk elements, the Directive No 2002/32/ES [51] defined the maximum values of elements in raw feedstuffs at $2 \mathrm{mg} / \mathrm{kg}$ for As, $30 \mathrm{mg} / \mathrm{kg}$ for $\mathrm{Pb}$ and $1 \mathrm{mg} / \mathrm{kg}$ for $\mathrm{Cd}$. Thus, the maximum contents of $\mathrm{Cd}$ in $T$. sect. Ruderalia exceeded this limit. For $P$. aviculare, no value exceeded these limits. Thus, although the results showed elevated soil As contents, availability of this element was low. The relatively high accumulation of $\mathrm{Cd}$ in the aboveground biomass of $T$. sect. Ruderalia growing in Cd-contaminated soil has also been determined in previous studies. For instance, Fröhlichová et al. [32] observed elevated $\mathrm{Cd}$ and other risk element contents in $T$. sect. Ruderalia growing in industrial areas affected by the historical mining and smelting activities, and Tůmová et al. [52] observed higher values in the vicinity of scrap metal deposits. Thus, T. sect. Ruderalia seems to be a plant with a high ability to accumulate $\mathrm{Cd}$ in its aboveground biomass. Within this study, the highest Cd contents were found inside the area of the hospital. Thus, areas with a high movement of people and with high traffic densities can be considered as a potential source of risk elements, which can be reflected in higher concentrations in the vegetation. However, this theory requires further investigation. 


\section{Conclusions}

To summarise the results, different approaches need to be taken into account for an evaluation of inorganic (risk elements) and organic (PAHs) substances in the soil and the vegetation in the area of Hradec Králové. In terms of risk elements, although elevated contents of soil $\mathrm{As}$ and $\mathrm{Cd}$ were found, no apparent source of these elements was identified. While As showed low plant availability, $\mathrm{Cd}$ was easily accumulated by the aboveground biomass of $T$. sect. Ruderalia, indicating a higher risk of vegetation contamination, esp. in areas with intensive movement of people and vehicles, such as the area of the city hospital. Thus, these potential hotspots of risk element contamination in the soil need to be investigated in more detail in further research works to verify wheather metioned activities can affect the $\mathrm{Cd}$ levels at these specific places. Concerning the PAHs, their contents in soils were low and did not represent any environmental risks. Thus, the absence of industrial plants and high traffic densities can be associated with low risks of soil contamination with PAHs.

\section{Acknowledgements}

Authors thank for financial support of the GAČR 17-00859S project and European Regional Development Fund - Project No. CZ.02.1.01/0.0/0.0/16 019/ 0000845. Correction and improvement of language was provided by Proof-Reading-Service.com Ltd., Devonshire Business Centre, Works Road, Letchworth Garden City SG6 1GJ, United Kingdom.

\section{Conflict of Interest}

The authors declare no conflict of interest.

\section{References}

1. WEI B., YANG L. A review of heavy metal contaminations in urban soils, urban road dusts and agricultural soils from China. Microchem. J. 94, 99, 2010.

2. LI Y., YUAN Y., SUN C., SUN T., LIU X., LI J., FANG L., FAN Z. Heavy metals in soil of an urban industrial zone in a metropolis: risk assessment and source apportionment. Stoch. Environ. Res. Risk Assess. 34, 435, 2020.

3. ALI M.U., LIU G.J., YOUSAF B., ULLAH H., ABBAS Q., MUNIR M.A.M. A systematic review on global pollution status of particulate matter-associated potential toxic elements and health perspectives in urban environment. Environ. Geochem. Health 41 (3), 1131, 2019.

4. HOLOUBEK I., DUŠEK L., SÁŇKA M., HOFMAN J., ČUPR P., JARKOVSKÝ J., ZBÍRAL J., KLÁNOVÁ J. Soil burdens of persistent organic pollutants - Their levels, fate and risk. Part I. Variation of concentration ranges according to different soil uses and locations. Environ. Pollut. 157 (12), 3207, 2009.

5. EHIGBOR M.J., IWEGBUE C.M.A., EGUAVOEN O.I., TESI G.O., MARTINCIGH B.S. Occurrence, sources and ecological and human health risks of polycyclic aromatic hydrocarbons in soils from some functional areas of the Nigerian megacity, Lagos. Environ. Geochem. Health DOI: 10.1007/s10653-020-00528-z, 2020.

6. MASTO R.E., SINGH M.K., ROUT T.K., KUMAR A., KUMAR S., GEORGE J., SELVI V.A., DUTTA P., TRIPATHI R.C., SRIVASTAVA N.K. Health risks from PAHs and potentially toxic elements in street dust of a coal mining area in India. Environ. Geochem. Health 41 (5), 1923, 2019.

7. GUNAWARDENA J., EGODAWATTA P., AYOKO G.A., GOONETILLEKE A. Role of traffic in atmospheric accumulation of heavy metals and polycyclic aromatic hydrocarbons. Atm. Environ. 54, 502, 2012.

8. WAWER M., MAGIERA T., OJHA G., APPEL E., KUSZA G., HU S., BASAVAIAH N. Traffic-related pollutants in roadside soils of different countries in Europe and Asia. Water Air Soil Pollut. 226, 216, 2015.

9. YAN X.D., ZHANG F., GAO D., ZENG C., XIANG W., ZHANG M. Accumulations of heavy metals in roadside soils close to Zhaling, Eling and Nam Co lakes in the Tibetan Plateau. Int. J. Environ. Res. Public Health 10 (6), 2384, 2013.

10. BEN SEGHIER T., BOUHADJERA K. Pollution assessment of heavy metals in roadside agricultural soils. Pol. J. Environ. Stud. 29 (4), 2855, 2020.

11. GUNEY M., ONAY T.T., COPTY N.K. Impact of overland traffic on heavy metal levels in highway dust and soils of Istanbul, Turkey. Environ. Monit. Assess. 164, 101, 2010.

12. WANG C., YE Z.R., WANG W., JIN M.Z. Traffic-related heavy metal contamination in urban areas and correlation with traffic activity in China. Transp. Res. Record 2571, 80, 2016.

13. OJURI O.O., TAIWO O.A., OLUWATUYI O.E. Heavy metal migration along a rural highway route: Ilesha-Akure roadside soil, Southwestern, Nigeria. Glob. Nest J. 18 (4), 742, 2016.

14. VIARD B., PIHAN F., PROMEYRAT S., PIHAN, J.C. Integrated assessment of heavy metal $(\mathrm{Pb}, \mathrm{Zn}, \mathrm{Cd})$ highway pollution: bioaccumulation in soil, Graminaceae and land snails. Chemosphere 55 (10), 1349, 2004.

15. MODLINGEROVÁ V., SZÁKOVÁ, J., SYSALOVÁ, J., TLUSTOŠ, P. The effect of intensive traffic on soil and vegetation risk element contents as affected by the distance from a highway. Plant Soil Environ. 58 (8), 379, 2012.

16. MORSE N., WALTER M.T., OSMOND D., HUNT W. Roadside soils show low plant available zinc and copper concentrations. Environ. Pollut. 209, 30, 2016.

17. CARRERO J.A., ARRIZABALAGA I., BUSTAMANTE J., GOIENAGA N., ARANA G., MADARIAGA J.M. Diagnosing the traffic impact on roadside soils through a multianalytical data analysis of the concentration profiles of traffic-related elements. Sci. Total Environ. 458-460, 427, 2013.

18. TEJEDA-AGRADANO M.C., GALLEGO S., VILA J., GRIFOLL M., ORTEGA-CALVO J.J. CANTOS, M. Influence of the sunflower rhizosphere on the biodegradation of PAH in soil. Soil Biol. Biochem. 57, 830, 2013.

19. DUAN L.C., NAIDU R., LIU Y.J., PALANISAMI T., DONG Z.M., MALLAVARAPU M., SEMPLE K.T. Effect 
of ageing on benzo[a]pyrene extractability in contrasting soils. J. Hazard. Mat. 296, 175, 2015.

20. KOTALOVÁ D., SZÁKOVÁ J., SYSALOVÁ J., TLUSTOŠ $P$. The contents of selected pollutants in soil and vegetation cover in Ostrava city section contaminated by industrial emissions (in Czech), Ochrana ovzduší 23 (3), 24, 2011.

21. LIANG S.Y., CUI J.L., BI X.Y., LUO X.S., LI X.D. Deciphering source contributions of trace metal contamination in urban soil, road dust, and foliar dust of Guangzhou, southern China. Sci. Total Environ. 695, 133596, 2019.

22. SHI G., CHEN Z., TENG J., BI C., ZHOU D., SUN C., LI Y., XU S. Fluxes, variability and sources of cadmium, lead, arsenic and mercury in dry atmospheric depositions in urban, suburban and rural areas. Environ. Res. 113, 28, 2012.

23. AL-TAANI A.A., NAZZAL Y., HOWARI F.M. Assessment of heavy metals in roadside dust along the Abu Dhabi-Al Ain National Highway, UAE. Environ. Earth Sci. 78 (14), 411, 2019.

24. TANG Z.W., CHAI M., CHENG J.L., JIN J., YANG Y.F., NIE Z.Q., HUANG Q.F. LI Y.H. Contamination and health risks of heavy metals in street dust from a coal mining city in eastern China. Ecotoxicol. Environ. Safe. 138, 83, 2017.

25. BORŮVKA L., HUANWEI C., KOZÁK J., KRIŠTOUFKOVÁ S. Heavy contamination of soil with cadmium, lead and zinc in the alluvium of the Litavka river. Rostl.Výr. 42 (12), 543, 1996.

26. KOŠNÁŘ Z., MERCL F., PERNÁ I., TLUSTOŠ P. Investigation of polycyclic aromatic hydrocarbon content in fly ash and bottom ash of biomass incineration plants in relation to the operating temperature and unburned carbon content. Sci. Total Environ. 563-546, 53, 2016.

27. MELOUN M., MILITKÝ J. Statistical analysis of the experimental data. (in Czech) Academia, Praha, 2004.

28. PUBLIC NOTICE No. 153/2016 about the conditions for the protection of the agricultural soil quality. Legal code of The Czech Republic, 2692, 2016.

29. YANG J., ZHANG C., TANG Y. Metal distribution in soils of an in-service urban parking lot. Environ. Monit. Assess. 187 (7), 478, 2015.

30. O'SHEA M.J., VANN D.R., HWANG W.T., GIERE R. A mineralogical and chemical investigation of road dust in Philadelphia, PA, USA. Environ. Sci. Pollut. Res. 27 (13), 14883, 2020.

31. LI X.D., POON C.S., LIU P.S. Heavy metal contamination of urban soils and street dusts in Hong Kong. Appl. Geochem. 16 (11-12), 1361, 2001.

32. FRÖHLICHOVÁ A., SZÁKOVÁ J., NAJMANOVÁ J., TLUSTOŠ P. An assessment of the risk of element contamination of urban and industrial areas using Taraxacum sect. Ruderalia as a bioindicator. Environ. Monit. Assess. 190, 150, 2018.

33. LI R.P., CAI G.Q., WANG J., OUYANG W, CHENG H.G., LIN C.Y. Contents and chemical forms of heavy metals in school and roadside topsoils and road-surface dust of Beijing. J. Soils Sedim. 14 (11), 1806, 2014.

34. DEHGHANI S., MOORE F., KESHAVARZI B., HALE B.A. Health risk implications of potentially toxic metals in street dust and surface soil of Tehran, Iran Ecotoxicol. Environ. Safe 136, 92, 2017.

35. PIERRI D. Environmental hazards resulting from the use of public roads in Krakow, Poland. Pol. J. Environ. Stud. 29 (4), 2803, 2020.

36. KOMÁREK M., TLUSTOŠ P., SZÁKOVÁ J., CHRASTNÝ V. The role of chloride salts in chemically enhanced phytoextraction of heavy metals from a contaminated agricultural soil. Bull. Environ. Contam. Toxicol. 78, 166, 2007.

37. BODZEK D., LUKS-BETLEJ K., JANOSZKA B. Occurrence of PAHs in various elements of environment in Zabrze (Upper Silesia, Poland). Water Air Soil Pollut. 103, 91, 1998

38. LIU Y.G., GAO P., SU J., DA SILVA E.B., DE OLIVEIRA L.M., TOWNSEND T., XIANG P. MA L.Q. PAHs in urban soils of two Florida cities: Background concentrations, distribution, and sources. Chemosphere 214, 220, 2019.

39. SHAMILISHVILY G., ABAKUMOV E. GABOV D. Polycyclic aromatic hydrocarbon in urban soils of an Eastern European megalopolis: distribution, source identification and cancer risk evaluation. Solid Earth 9 (3), 669, 2018

40. HOWARD W.M., WANG G.D., GONZALES C.H.R., POWELL E.T., QUACH B.L., QUACH V.N. PAHs and metals in the soils of inner-city and suburban New Orleans, Louisiana, USA. Environ. Toxicol. Pharmacol. 18 (3), 243, 2004.

41. QI P.Z., QU C.K., ALBANESE S., LIMA A., CICCHELLA D., HOPE D., CERINO P., PIZZOLANTE A., ZHENG H., LI J.J., DE VIVO B. Investigation of polycyclic aromatic hydrocarbons in soils from Caserta provincial territory, southern Italy: Spatial distribution, source apportionment, and risk assessment. J. Hazard. Mat. 383, 121158, 2020.

42. BIELINSKA E.J., FUTA B., UKALSKA-JARUGA A., WEBER J., CHMIELEWSKI S., WESOLOWSKA S., MOCEK-PLOCINIAK A., PATKOWSKI K., MIELNIK L. Mutual relations between PAHs derived from atmospheric deposition, enzymatic activity, and humic substances in soils of differently urbanized areas. J. Soils Sedim. 18 (8), 2682, 2018.

43. HILLER E., LACHKA L., JURKOVIC L., VOZAR J. Polycyclic aromatic hydrocarbons in urban soils from kindergartens and playgrounds in Bratislava, the capital city of Slovakia. Environ. Earth Sci. 73 (11), 7147, 2015.

44. KUMAR V., KOTHIYAL N.C., SARUCHI Studies on carcinogenic PAHs emission generated by vehicles and its correlation to fuel and engine types. Polish J. Chem. Technol. 16 (1), 48, 2014.

45. BAO H.Y., HOU S.W., NIU H., TIAN K., LIU X.P., WU F.Y. Status, sources, and risk assessment of polycyclic aromatic hydrocarbons in urban soils of Xi'an, China. Environ. Sci. Pollut. Res. 25 (19), 18947, 2018.

46. SLÁDKOVÁ A., SZÁKOVÁ J., HAVELCOVÁ M., NAJMANOVÁ J., TLUSTOŠ P. The contents of selected risk elements and organic pollutants in soil and vegetation within a former military area. Soil Sedim. Contam. 24 (3), 325, 2015.

47. VOUTSA D., GRIMANIS A., SAMARA C. Trace elements in vegetables grown in an industrial area in relation to soil and air particulate matter. Environ. Pollut. 94 (3), 325, 1996

48. KIM H.S., KIM K.R., KIM W.I., OWENS G., KIM K.H. Influence of road proximity on the concentrations of heavy metals in Korean urban agricultural soils and crops. Arch. Environ. Contam. Toxicol. 72 (2), 260, 2017

49. TOMAŠEVIĆ M., VUKMIROVIĆ Z., RAJŠIĆ S., TASIĆ M., STEVANOVIĆ B. Characterization of trace metal particles deposited on some deciduous tree leaves in an urban area. Chemosphere 61 (6), 753, 2005.

50. SZÁKOVÁ J., SYSALOVÁ J., TLUSTOŠ P. Particular aspects of environmental impact of potentially risk 
elements from airborne particulate matter. Plant Soil Environ. 51 (8), 376, 2005.

51. DIRECTIVE No. 2002/32/ES of European Parliament and Council of Europe concerning xenobiotics in feedstuffs, 2002.
52. TŮMOVÁ K., SZÁKOVÁ J., NAJMANOVÁ J., TLUSTOŠ P. Scrap metal deposits as potential sources of enhanced risk in soil and vegetation. Pol. J. Environ. Stud. 29 (1), 841, 2020. 